\title{
THE INDONESIAN DISABILITY NATIONAL COMMISSION AS A STRATEGIC POLICY IN FULFILLING THE RIGHTS OF PEOPLE WITH DISABILITY
}

\author{
Galuh Wahyu Kumalasari \\ Faculty of Law, Universitas Muhammadiyah Surakarta, Indonesia \\ gwk744@ums.ac.id
}

\begin{abstract}
The disability or different ability is every people who had physical limitation, intellectual, mental, and/or sensory for a long time in interacting with their environment, could run into obstacles and difficulties to participate in full and effective with other citizens by equality rights. The law 8/2016 about people with disability is being law enforcement to fulfill the rights for the people with disability. Social Affairs Ministry through the Social Directorate of Disability Rehabilitation is the instrument of the state to implement the fulfillment of the rights. This writing is used normative juridical method to dig the formation policy of the National Commission with Disability to guarantee the disability rights. This study found that function given to social affairs ministry actually flawed, considering rights of people with disabilities is not simply about economic needs, but also the right to life, health, education, accessibility, political, and others. There are so many disabilities in various areas experienced discrimination and treated very inhuman, not only related accessibility but also about neglect practices and put the people with disabilities in a stocks. The formation of a national commission with disability as instructed in article 131-134 Act 8/2016 is very urgent to crystallize, so the implementation of the disability rights can be optimized. The formation of the national commission with disability will give certainty of a special institution that focus to handle and ensure the fulfillment rights of people with disabilities as citizens.
\end{abstract}

Keywords : The Disability National Commission, The Disability Rights, Different Ability

\section{Introduction}

The percentage people with disability according to the research of Universitas Indonesia reached $12.15 \%$ of the Indonesian population, $51,12 \%$ of the population will be employed in the workplace. For people with disability, 20,27\% of them participated in the world of work ( ILO \& LPEM FEB Universitas Indonesia , 2016). 
Table 1. The Percentage of People with Disability

\begin{tabular}{lll}
\hline & People with Disability & $\begin{array}{l}\text { People with serious } \\
\text { disability }\end{array}$ \\
\hline Informal & $65,55 \%$ & 75,8 \\
Formal & $34,45 \%$ & 24,2 \\
$\quad$ TOTAL & $100 \%$ & $100 \%$
\end{tabular}

Looking at the data, there are still $48,88 \%$ people with disability who still have no access to work.

Furthermore, the problems experienced by people with disability not only related to employment, but also about education, health, public facilities and the political right as citizens. The people with disability often experienced discrimination in efforts into the fulfillment of those rights. Meanwhile, the international regulation has arranged that people with disability have the same rights with people with non disable. International Covenant on Civil and Political Rights (ICCPR) and also International Covenant on Economic, Social and Cultural Rights (ICESCR) and as a specific The Convention on The Rights of Persons With Disability (CRPD) guaranteed the rights of the people with disabilities..

CRPD as a convention on the rights of people with a disability, it is ratified by the state of the Republic of Indonesia in The Law Number 19/2011 on People with Disabilities (next abbreviated The Law Number 19 / 2011) regarding the ratification of the CRPD. CRPD is international human rights instrument and national in an effort to reverence, the fulfillment of and protection of a right of people with disabilities in Indonesia (Development Tool and Human Rights Instrument). The purpose of this convention is to advance, protect, and to ensure the fundamental rights and liberty to all the people with a disability. Moreover, as well as respect for human dignity of people with a disability as an integral (inherent dignity) (Explanation of The Law Number 19 / 2011 regarding the ratification of the CRPD, 2011).

The CRPD's 25 preamble paragraphs and 50 articles provide a framework within which disability rights may be addressed in the global context. The aim of the drafts was not to create 'new' or special rights for persons with disabilities, but instead to articulate how existing human rights obligations apply specifically to disabled persons.

Although the CRPD has substantial support around the world, not all nations have embraced it in its entirety. The United States, for example, has signed, but not ratified the CRPD; thereby agreeing with the instrument's purpose if not its specific provisions. Hesitancy to ratify the agreement likely has many explanations. Legal literature on the subject, for 
example, predicts a litany of potential changes to how the United States runs everything from its schools to its prisons (Katherine D. DeMarco : 2012). For the most part, the laws in the United States match the rigor required by the Convention, but there are gaps between the protections offered by the United States and the CRPD (Michael Stein, and Michael Waterstone : 2008). Differences can be observed regarding the degree of positive equality measures in areas such as vocational education; the existence of affirmative policies or requirements aimed at addressing social stigmas surrounding disability; limitations on the right to live in a community based on services that do not require fundamental alterations to serve persons with disabilities; and difficulties concerning access to justice (Michael Stein, and Michael Waterstone : 2008).

The discrimination actually not only happened in the workplace but also happened in the education. The results of interviews with one speaker named WL (a people with disability with the tools a stick and/or a chair wheels) on the July 142013 are continuing education to high schools, the majority schools in the Solo haven't facility that can be accessed by people with disability especially with wheelchair. Finally WL given by choosing public schools where concerned shall up and down households using a crutches which of need extra energy compared to using a wheelchair (Interview, 2013). In January 52017 when WL will continue to college, the same problem still happens, the best universities in Solo have not comfortable to people with disability, especially those related to facilities of the campus (Interview, 2017).

Handling and for fulfilling the right of people with a disability is problems that should be identified the solution. Many people with disability who become beggar in many regions especially at a traffic light and in crowded places. These conditions become an evidence of inappropriate facilitation from government against people with disability

Social affairs ministry c.q. The Directorate Social Rehabilitation of people with disability were the ones who given authority by the state to handle the disability. This authority get much criticized from citizen because perform to handle problem of people with disabilities are not optimally. It is important to get a special agency who handles people with disability, because this problems are really crucial and concerning to the right of citizens. Other countries such as Philippines, Malta, India and The United States has have a national institute with disability as the realization of the concern on the fulfillment of rights of people disability.

The law Number 8/2016 of people with disability through article 131-134 said to the establishment of the national commission with disability in Indonesia. The regulation didn't mention about when a term the commission supposed to be formed, so at the end of one year of the regulation, there has been no the realization on the establishment of this institutions. The national commission with disability this shall be constituted, in addition to meet it is mentioned by the law number $8 / 2016$ and it were really needed by the people with disability. 


\section{Method and Materials}

This research using the juridical normative research, the process of discovery the rule of law, a principle of law and doctrines in order to overcome legal issues. The law research carried out to produce argument, the theory or new concepts that is prescriptive in order to solve a problem (Peter Mahmud Marzuki, 2010). A source of materials research obtained by conducted a study of literature and interview to the speakers. Literature used originates from the journal, book, legislation and the source of website pertaining to issues with disability. Interview have been done on several speakers with disability and also activist who concerned with the rights of disability people.

\section{Results and Discussion}

The fulfillment of rights of the people with disabilities as citizens is a problem thet important to solve. This thought started from the condition right now where still often occur discrimination against people with disability. Not only for accessibility, facilities, and opportunities, but also related about the term. According to an interview with Mrs. Ipung (activists of people with disabilities rights from Yogyakarta) on February 122017 stated that actually the people with disability mind with the term "disability", they more comfortable called by difable compared to disable. The reason is because disable means have no power, have no abilities, but difable means different ability or having capabilities but different with non disabilities people. People with disability have not no capability, but they have different capabilities. Nevertheless, a term will be used in this research was with disability, in accordance with the provisions The Law Number 8/2016 of People with disabilities.

\subsection{Discrimination Against People With Disability}

The law number $39 / 1999$ about human rights at the article 1 paragraph (3) mentioned that discrimination is any restriction, harassment, or isolation who directly or indirectly based on differing man on the basis of religion, tribe, race, ethnic, group, the social status, economic status, sex, language, and political beliefs, that result in unemployment, deception or the removal of recognition, execution or the use of human rights and basic freedoms in the life of, good individual and collective in the political field, economic, law, social, culture, and another life aspects. Discriminations for it occur in people with disability the results of interviews to especially with regard with some things follows:

\section{Education}

Discrimination in education one experienced by $\mathrm{WL}$ and $\mathrm{H}$ based on interviews in January 5 2017, education facilities in general are still inadequate of people with disabilities. To physically disability, many of them have the ability intellectual 
adequate to contested in common schools, but mostly of the schools they weren't going to facilitate a wheelchair, because it is still use stairs and there is no way obliquely specifically disable. Another experience expressed by Risnawati Utami (disability which is now the one of the representatives of indonesia in the United Nation) at around 2013, Risnawati told that when she at college in one of campus in Solo it is difficult for them to follow because she had to up and down the stairs, while herself in a wheelchair, fortunately many friends willing to help.

\section{Occupation}

One of awkward experienced by IAH who was interviewed on December 24 2016. She is a legal scholar who looking for a job. Several times she got the call work, but at the interview, suddenly the interviewer give awkward expression after seeing the way she walked, because she got polio. She feels take offense with that expression. "I do not mind if not accepted for that job because of the inadequate intellectual ability, but if it is because of the physical condition, it's not fair", she said.

\section{The Political Rights}

In general can be seen that very few people with disabilities that can be seated in government, they usually will fall on the fit and proper tests. Sure it thereby very aggression their political rights as a citizens.

Besides the discrimination mentioned above about the disability felt a growing down because some condition that emerge from the community. These conditions of them are:

1. Peoplewith disabilities considered have insufficient ability in education, employment and in matters of politics.

2. Disability often were victims of crime/ violent crime physically, psychic and sacrilegious.

3. Neglect of disability. In indonesia still widespread deprivation on disability, for example to people down syndrome. In addition in a foundation in Solo, according to the interviews of several people who have been living there with the initials $\mathrm{H}$ in july 2013, expressed that many times they are given food who has not fresh and almost stale by nanny in this institution, or sometimes vegetable ripe who included in the refrigerator then warmed back. Meanwhile, they paid the whole months to stay at there.

\subsection{Indonesian Nasional Commission of Disabilities}

The various problems of disability actually have to be known by the government. So far through the ministry of social casu quo The directorate of social rehabilitation people with a disability the government make every effort to social solve the problems of people with disabilities. But it is important to note, that fulfillment of the rights toward the 
disability should not just limited to the scope of social ministry. The main reason is people with a disability also really need access to other ministries for example the ministry of health, education, culture, youth and sports, and others. So the supposed to be formed an agency that specifically deal with the fulfillment of the rights of people with disability as well as they seek independence. The hope, the people with a disability will be compete with and accepted in the community because of its ability, not only because of compassion.

Prosperity and independence of people with disabilities get a lot of attention. The latest phenomenon is the online platform kerjabilitas.com which are engaged in employment of people with disabilities. This platform cooperate with about 900 companies in Indonesia. Kerjabilitas.com gives means of people with disabilities to work in the formal sector and bring with companies that provide the opportunity to people with disability. Kerjabilitas.com stated that in some cases proven that performance people with disability can three times as better than non with disability. For example for the deaf people, they more concentration with his work relatively because they did not disturbed by colleagues chattering and others. While non-interest disable often lost concentration when they colleagues for a chat so for a moment left his job. Currently kerjabilitas.com are able to help less than 100 the disability for jobs in formal sector (Broadcast Metro TV, 2017).

One of the speakers, IAH also said that she currently working on a private bank in Yogyakarta through kerjabilitas.com platform. She is able to work with polio optimally in customer service in the private bank. The assessment proved that her performance pretty well and would not be hampered at all and not affected by the legs with polio.

The kerjabilitas.com shows that private was able to take the roles and benefits are from the people with disability. Looking at these conditions, the government should do able to provide more chances for people with disabilities to be independent and obtain their rights as citizens. Through the national disability it was reflected from Indonesia, the government actually can embrace and cooperate with private sector in solving the problems pertaining to disability.

The importance of the formation of the national disability indonesia, such as:

1. People with disabilities has their rights as citizens and the responsibilities of the government/state to guarantee the fulfilment of their rights, such as right to life , the right to get jobs, the right to obtain an education, health insurance and the right to join in politics.

2. It was reflected from one body which specializes in handling of disability will give more chances in dealing with fulfilment of the rights of disability. The directorate rehabilitation disability is under social affairs ministry during is not yet optimal deal with problems with disabilities, because discrimination is still very widespread. 
3. The establishment of the national commission disability in indonesia is mentioned in the law number 82016 about people with a disability. The bill are aged one year since the promulgation of, however has not realized the existence of the national commission until now. The national commission is a nonstructural institution that will be independent .

The work program that must be implemented by the national commission disability of indonesia:

1. Provide training so that people with a disability having skills and can be accepted in the workplace because of its ability, both intellectually and skills;

2. Open job opportunities for people with disability;

3. Making sure that 2 percent workers as a civil servant, and 1 percents for private workers like mentioned in the law number 8/2016;

4. Based on the law number of disability are implementing monitoring, evaluation, and advocacy the respect, protection, and working rights of people with disabilities and report it to the president.

Pursuant to article 133 the law number 8/2016, in order to implement the job, the national disability functions of them:

1 Drafting Plan and activities in an effort to the respect, protection and fulfilment of rights of people with disabilities;

2 Monitoring and evaluation of the respect, protection and fulfilment of rights of people with disabilities;

3 Advocating the respect, protection and fulfilment of disability; and

4 Implementation of the cooperation in handling people with disability stakeholders.

When the national commission with disability the indonesian are formed and capable of performing duties and functions as mentioned above, so will bring benefit for the people disabbilitas, including:

1 Increasing the skills and independence people with disability;

2 Increase the bargaining positions people with disability on social environment;

3 Equalizes people with disability with non with disability;

4 The fulfillment of rights of people with disabilities as citizens.

\subsection{The National Commission For Disability In Various Countries}

Establishing a national comission with disabilities is a very important thing. Even it is already aware by the countries in the world. The countries such as Philippines, Malta, India and The United States has first national forming an institution that specifically handle the disability problems. These institutions can be explained as follows: 


\section{Philipines}

Filipina memiliki National Council on Disability Affairs. The National Council on Disability Affairs (NCDA) is the national government agency mandated to formulate policies and coordinate the activities of all agencies, whether public or private, concerning disability issues and concerns. As such, the NCDA is the lead agency tasked to steer the course of program development for persons with disabilities and the delivery of services to the sector. NCDA has a tagline "Towards Full Participation and Equality of Rights and Opportunities for Persons With Disailities (http://www.ncda.gov.ph/, 2009).

The NCDA is tasked to monitor the implementation of several laws to ensure the protection of PWDs' civil and political rights. These laws include Republic Act No 7277 (Magna Carta for Disabled Persons), Batas Pambansa Blg. 344 (Accessibility Law), Republic Act 6759 (White Cane Act) and ILO Convention No. 159 (Vocational Rehabilitation of Persons With Disability). It has also been tasked, through Proclamation No. 125, to coordinate activities and to monitor the observance of the Asian and Pacific Decade of Disabled Persons (1993-2002) in the Philippines. Proclamation No. 125 was issued by the President on January 15, 1993, to enjoin both the government and the private entities to organize projects based on the policy categories mentioned in the agenda for action of the decade (http://www.ncda.gov.ph/, 2009).

\section{Malta}

Kummissjoni Nazzionali Persuni B'Dizabilita or The National Commission Persons with Disability is committed to rendering Maltese society an inclusive one, in a way that persons with disability reach their full potential in all aspects of life, enjoying a high quality of life thanks to equal opportunities. In fulfilling this mission, KNPD works in order to eliminate any form of direct or indirect social discrimination against persons with disability and their families while providing them with the necessary assistance and support.

The National Commission Persons with Disability was founded on the 3rd of November 1987, when the then Minister of Social Policy, the Hon. Dr Louis Galea, had made a parliamentary statement announcing that he had appointed the first KNPD members.On the 10th of February 2000, KNPD was officially founded, this time in accordance with Act No. 1 of the year 2000, the Equal Opportunities (Persons with Disability Act.

It has the duty to raise awareness about the capabilities and contributions of persons with disability and combat prejudices or harmful behaviour in their regard stemming from stereotypes. It is also expected to identify the needs of persons with 
disabilities, their families and voluntary bodies working in the field of disability and promote policies, encourage research and best practice as well as collaborate with local and international entities in order to achieve these goals. It is also responsible to monitor government initiatives addressing their needs, suggest changes in laws and coordinate initiatives taken by different departments. The law empowers KNPD to investigate complaints it receives about breach of rights arising from discrimination, the enforcement of such rights as well as to promote, protect and monitor the implementation of the United Nations Convention on the Rights of Persons with Disability and to monitor Guardianship Orders. KNPD provides a number of services for persons with disability and their families. The services provided include Special ID Card, Blue Sticker, Assistive Apparatus Service and the exemption of payment of road licenses (http://www.knpd.org/, 2012).

\section{India}

India had Office of The Chief Commissioner for Persons with Disabilities below The Ministry of Social Justice and Empowerment, Government of India. The Office of the Chief Commissioner for Persons with Disabilities has been set up under Section 57 of the Persons with Disabilities (Equal Opportunities, Protection of Rights \& Full Participation) Act, 1995 and has been mandated to take steps to safeguard the rights of persons with disabilities. As per Census 2011, there were 2.68 Crores $(2.21 \%$ of the Population) persons with disabilities. The National Sample Survey Organization (NSSO) in its 58th rounds during July-December 2002, estimated that the number of persons with disabilities in India was 1.85 Crores (1.85\% of Population).

The Persons with Disabilities (Equal Opportunities, Protection of Rights And Full Participation) Act. 1995. This was published on 1st January 1996 and was notified on 7th February, 1996. The Persons with Disabilities Act basically enlists facilities that persons with different types of disabilities would be entitled to and the responsibilities and obligations which are placed on the Government of India, State Governments, local bodies and establishments in this behalf. It broadly includes measures for prevention and early detection of disabilities, education, employment, social security, research and manpower development, barrier-free access and preferences and facilities that are available to such persons and the action which needs to be taken to avoid any discrimination against persons with disabilities. It has been provided in the Act that there shall be a Chief Commissioner at the Govt. of India level and a Commissioner in each State of the Union/UT, who would be broadly responsible to:

a. Monitor the utilization of funds disbursed by the Central Government and compliance of various provisions of the Act. 
b. Safeguard the rights and facilities made available to persons with disabilities. Coordinate work of the State Commissioners.

(http://www.ccdisabilities.nic.in, 2010)

\section{United States of America}

USA since 1978 had National Council on Disability (NCD). NCD is an independent federal agency charged with advising the President, Congress, and other federal agencies regarding policies, programs, practices, and procedures that affect people with disabilities. NCD is comprised of a team of Presidential and Congressional appointees, an Executive Director appointed by the Chair, and a full-time professional staff.

First established as a small advisory Council within the Department of Education in 1978, NCD was transformed into an independent agency in 1984 and charged with reviewing all federal disability programs and policies. In 1986, NCD recommended enactment of an Americans with Disabilities Act, and then drafted the first version of the bill introduce in the House and Senate in 1988. Since enactment of the ADA in 1990 , NCD has continued to play a leading role in analyzing the needs of people with disabilities, crafting policy solutions, and advising the President and Congress.

NCD's mission is to be a trusted advisor, in collaboration with people with disabilities to The President; The Congress; Federal entities, State, tribal communities; and local governments; and Other entities and organizations. NCD fulfills its advisory roles regarding disability policies, programs, procedures, and practices that enhance equal opportunity by:

a. Convening stakeholders to acquire timely and relevant input for recommendations and action steps;

b. Gathering and analyzing data and other information;

c. Engaging and influencing current debates and agendas;

d. Identifying and formulating solutions to emerging and long-standing challenges; and

e. Providing tools to facilitate effective implementation

(https://ncd.gov/, 1978) 


\section{Conclusion}

The fulfilment the rights of people with disability is an authority and obligation to be protected by the state. The implementation of this authority was originally held by social affairs ministry c. q. The directorate rehabilitation disability. The directorate was not effective in work because it proved still prevalent discrimination against disability. Looking at these conditions, so shall be constituted a special institution authorized to handle issues concerning disability. It thereby in line with the law number $8 / 2016$ on people with disability, to establish a special institution as soon as possible. This institution is important to fulfil the rights of disability to get larger concern by the government, considering $12,15 \%$ Indonesians is disability.

\section{References}

Interview Miss WL, July 142013

Interview Miss WL, January 52017

Interview Miss H, January 52017

Interview Mrs Ipung, February 122017

Interview Miss IAH, December 242016

ILO and LPEM FEB Universitas Indonesia. (2016). Disability and Work. http://ilo.org/global/topics/disability-and-work/lang--en/index.htm Accessed July, 152017

Katherine D. DeMarco. (2012). "Disabled by Solitude: The Convention on the Rights of Persons with Disabilities and Its Impact on the Use of Supermax Solitary Confinement." University of Miami Law Review 66 (2012): 523-65.

Kerjabilitas, (2017), Kerjabilitas Situs Pencari Kerja Bagi Penyandang Difabel http://video.metrotvnews.com/play/2017/07/17/730567/kerjabilitas-situs-pencari-kerja-bagipenyandang-difabel Accessed July 252017

Kummissjoni Nazzuonali Persuni B’Dizabilita, (2012), http://www.knpd.org/ Accessed July 20 2017

Michael Stein, and Michael Waterstone. (2008). "Finding the Gaps: A Comparative Analysis of Disability Laws in the U.S. to the U.N Convention on the Rights of Persons with Disabilities."National Council on Disability, 12 May 2008. Available online: http://www.ncd.gov/publications/2008/May122008 (accessed on 22 May 2017)

National Council on Disability Affairs, (2009), http://www.ncda.gov.ph/ Accessed July 202017

National Council on Disability, (1978), http://www.ncd.gov/ Accessed July 202017

Peter Mahmud Marzuki, (2010), Penelitian Hukum, Jakarta: Prenada Media Group, Page 35

\section{0}

Diponegoro Law Review, October 2017, Volume 02, Number 02 
Risnawati Utami, 2013, Workshop Disabilitas, in Loji Hotel by Organisasi Harapan Nasional (OHANA) Yogyakarta and Universitas Sebelas Maret Surakarta

The Chief Commissioner for Persons with Disabilities, (2010), http://www.ccdisabilities.nic.in Accessed July 202017

The Law of Indonesia Number 19/2011 on Ratification of CRPD

The Law of Indonesia Number 39/1999 on Human Rights

United Nations. "Convention and Optional Protocol Signatures and Ratifications." Available online: http://www.un.org/disabilities/countries.asp?id=166 (accessed on 22 May 2017) 